\section{Sudies of the Compositions of Humic Acids from Amazonian Dark Earth Soils}

LILVLNOH. NOVOTNY, *, H,

EDUARDOR. DEAZEVEDO

TIOI.BONAGAMBA,

TONY 1. F. CUNHA, BEATA E. MADART,

WNLCIUS DE M.BENLIES, AND

MICHAEL H.B. HAYES:

Fmbrapa Solos, R. Jartim Botanico, 1.024. Pio de Janeiro-RI, brazb, 22460-000, Chemical and Enwronmental Scierces,

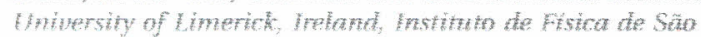

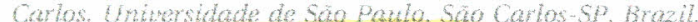
Embrapa Semi-Árido Cx.P. 23. Perrolina-PE, Brazil, 56300-970, and Embroph hroz e Folide, ChP. 170 Santo Antonio de Goids-GO, Brazin, 75aza- Oro

The compositions of humic acids (HAs) isolated from cutivated and forested "Terra Preta de Indio" or Amazonian Dark Earth solls lanthropogenic soils) were compared with those from adjacent non-anthopogenic soils lcontrol soils) using elemental and themogravmetric analyses, and a variety of solid-state muclear magagtic yesonance techniques. The thermogravimetric index, which indicates the molecular thermal resistance, was greater for the anthropogenic solls than for the control soils suggesting polycyclic aromatic components in the former. The cultwated anthropogenic solls were more aniched in C and depleted in $H$ than the anthropogenic soils under forest, as the result of the selective degradation of aliphatic structures and the possible enrichment of H-deficient condensed aromatic structures. The combination of variable ampltude cross-polarization (VACP) and chemical shift anisotropy with total suppression of spinning sidebands axperments with composite $\pi$ pulses could be used to quantify the aromaticity of the HAs from the anthropogenic soils. From principal component analysis, using the VACP spectra, it was possible to separate the different constituents of the HAs, such as the carboxylated aromatic structures, from the anthropogenic soils and plant derved compounds. The data show that the HAs from anthropogenic soils have high contents of aryl and ionisable oxygenated functionat groups, and the major functionalities from adiacent control soils are oxygenated functional groups from labile structures (carbohydrates, peptides, and with evidence for lignin structurest. The anthropogenic solis $\mathrm{HAs}$ can be considered to be more recalcitrant and with more stable reactive functional groups which may, in part, explain their more sustainable fertility due to the organic matter contribution to the soil cation exchange capacity.

"Conesponding author phone: +363 6t 202631 ; $6 x$ : -35361

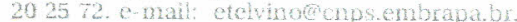

R. Jardirn Botanica.

University of limerict

Universidade de Săo Panlo.

limbrapa Semi-Arido.

- Embrapa Arroz c Feilăo.
Introduction

Most of the soils in the Amazon are acidic, with low cationexchange camaciry (CFC), low fartity, and tow urnduction potental. The dominating soil types are Ferralsols, Acrisols, and Sesquisols that cover $70 \%$ of the region. In this environ. ment, where soil fortility is a limiting factor for sustainable agricultual development, the "Tera Preth de Indio" soils occur. These are also known as Amazonan Dark Earths. Anthropogenic Dark Earths (ADE), Indian Black Earths, or Archaeological Dark Earths. ADE are soils that have an archeoanthropedogenic horizon; that is a suface hoikon of vitying depth in soil profiles that feature elevated organic matter (OM) contents and ceramic pieces or lithicartelacts ( 1 ). Thest occur in isolated patches, most of which do not exceed 2 ha but larger sites, with areas up to 350 ha, have also been reported (2). ADE soils howe developed on virtually all soit types (Ferralsols, Acrisols. Sesquisols, Podzols, Arenosols, etc, and can be foud in all eco-regions and landscenes of the Amazon basin. ADE soils are commonly found near rivers and strems, but due to the lack of interior roat systems. it has been difficult to access areas remote from xivers. For that reason, although the abundance of ADE sites is high there are no reliable data for the total ADF area in the Amazon

It is now generally accepted that ADE. sots are of preColumbian origin (3), although there are several hypotheses with regard to the processes of their formation. It is not clear whether the soils resulted from intentional soil improvement mocesses, or were byproducts of the agrioutural and household activities of the indigenous populations. The twelling places in the pre-Columbian past gave nise to accumulations of plant and animal dobris, as well as to harge amounts of ashes and of bonfre residues (charcoal) and seyeral chenical elements, such as P, Mg, Zn, Cu, Ca, Sr, and Ba, which represent a geochented signature of human occupation (4). These accumbations are likely to be maion contributors to the fomation of the fertile soils.

Pyrogenic carbon derived substances are found in bumified materials in tropical solls where there are historical records of vegetation buming, and pyrogenic carbon is also an important component in Brazhian Savanna sols (5), and in areas of high alutude black soils (6). The organit components in these soils have the common chamacteristics of high resistance to themodegradation, and bave charge chanacteristics to which the high soil CEC values are atribured. Given its high stability and reactivity, pyrogenio carbon is of great importance for the condirioning of tropical soils subjected to climatic conditions that favor OM nineralization, and where the clay fraction has low CEC values

Pyrogenic carton is not, of caurse, restricted to trapical

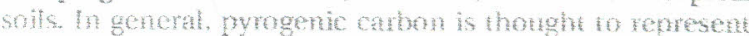
betwen 1 and $6 \%$ of the total soll organic carbon $(O C)(T)$ and in general, estimates areless then $10 \%$ of the soll organic matter (SOM) (8). It can reach 78 क in natwe matrie in the U.S. (9), 35\% in some U.S. agricultural soils (10), up to $30 \%$ in Auswatian solls (7), up to $45 \%$ in German Chemozems (12), and up $65 \%$ in Cunadian Chemozems (13). However. these values can be overestimates because of problems in obtaining accirate data (14-76).

The high ferditiv of $\mathrm{ADE}$, and especially its sustamability. is attributed to the high levels of OM and to the physicalchemical propertes of the OM. ADE have cabon contents up to $150 \mathrm{~g} \mathrm{C} \mathrm{kg}^{-1}$ soil compared to $20-30 \mathrm{~g} \mathrm{C} \mathrm{kg}^{-1}$ in the surrounding soils $(3,77,78)$. Addirionally, the degth to which C enrichment occurs may be greater than $200 \mathrm{~cm}$ (with average values of the order of $40-50 \mathrm{~cm}$, whereas $\mathrm{OM}$ in the 
surrounding soils is in the top $10-20 \mathrm{~cm}$. Therefore, the total $\mathrm{C}$ stored in ADE soils can be an order of magnitude higher than in adjacent soils and this additional $\mathrm{C}$ is mainly in the form of pyrogenic carbon (18).

ADE are characterized by higher P contents $(200-400 \mathrm{mg}$ $\mathrm{kg}^{-1}$ ), higher CEC, $\mathrm{pH}$, and base saturation values, and with higher stable OM contents than the surrounding soils $(17$, 18). This OM is up to six times more stable than that in adjacent soils that do not have an archeo-anthropedogenic horizon (18).

The contribution of pyrogenic carbon to soil fertility and to its sustainability is attributed mainly to its composition and to its molecular structures (18). Pyrogenic carbon is highly resistant to thermal, chemical, and photo-oxidation $(19,20)$. Its contribution to soil fertility is attributed to the chemical and biochemical transformations of carbonized residues that resulted from natural or induced burning of the biomass that led to the partial carbonization of ligno-cellulosic materials (14). Its core consists of polyaromatic units of different sizes and with different organizational levels (21). Although pyrogenic carbon does undergo some natural degradation in soil (22), it has a high resistance to degradation and its incorporation in the soil is an important mechanism of carbon sequestration $(23,24)$. Because of partial oxdation. the peripheral aromatic units contain acidic (carboxyl) substituents $(27,25)$ that give rise to high $C E C$ values. This is very similar to the organic $\mathrm{C}$ in Mollisols of the mid-west U.S. thought to be formed by the burning of vegetation over prolonged periods $[26]$.

The humic components derived from pyrogenic carbon are also characterized by hydrogen-deficient, condensed aromatic structures, and with high charge density due to carboxylic groups linked principally to the aromatic core (2l).

It is now being recognized that the production systems of former, native cultures may provide knowledge tbat could serve as a basis for the development of modern sustainable management systems in agriculture and the ADE of the Amazon basin are remarkable examples of sustainable ancient agricultural management systems in tropical ecosystems. Thus, by investigating the compositions of the components responsible for the sustainable fertility of ADE soits, it may be possible to reconstruct the conditions that gave rise to the phenomenon (27) and to gain an understanding of technologies that could generate improved fertility in other soil systems.

Toward that end we have, using solid-state nuclear magnetic resonance (NMR), elemental ( $\mathrm{CHN}$ ), and themogravimetric analyses, compared the compositions of humic acids (HAS) isotated from the ADE snits with those from adjacent non-anthropogenic soils. Additionally, the methodology proposal by Mao and Schmidt-Rohr (28) was adapted to quantify the aromatic groups using chemical shift anjsotropy $(C S A)$ filters. Small modifications were made to this methodology in orfer to adant the procedure for the quantification of pyrogenic carbon, which tas characteriscics very different from those of the usual components of SOM.

\section{Experimental Section}

Composite samples Irom 10 sub-samples were taken from surface $(0-20 \mathrm{~cm})$ Amazomian soils having archeo-anthropedogenic horizons. In the case of $A D E$ the presence of ceramic artifacts is the most detining factor. All soils defined as ADE in this paper had ceramic artifacts. Six of the soils were under forest fanthopogenic soil wider forest $-A S-F$ ) and twelve were cultivated fcultivated anthopogenic soilsAS-C). Additionally, samples were taken from four adjacent non-anthropogenic contzol soils under forest (non-anthopogenic soils-control soils). Samples were sieved ( $2 \mathrm{~mm}$ ) and air-dried. The HAs were extracted using the method recommended by the International Humic Substances
Society (29). Details about localization of the samples site (Figure SI-1) and extraction procedure can be found in the Supporting Information.

A TGA-50 SHIMADZU thermogravimetric analyzer was used to obtain thermo-decomposition curves for $3.3 \pm 0.1$ mg samples of HAs in static air. Samples were stabilized at $303 \mathrm{~K}$ and heating was carried out at $5 \mathrm{~K} \mathrm{~min}^{-1}$ to $378 \mathrm{~K}$, and then held for $10 \mathrm{~min}$, followed by heating at $5 \mathrm{~K} \mathrm{~min}^{-1}$ up to $923 \mathrm{~K}(6)$. The weight loss at $378 \mathrm{~K}$ was considered to be from sample moisture. The residue at the end of the heating was attributed to the ash content. Weight losses between 378 and $623 \mathrm{~K}$, and between 623 and $923 \mathrm{~K}$ were determined, and the ratios of these two peak areas represent the resistance of the humic substances to thermal degradation. This is defined as a thermogravimetric index (TGI) (6).

The C content of the soil samples and the elemental compositions of the HAs were determined in two replicates using a Perkin-Elmer $2400 \mathrm{CHN}$ analyzer. The $\mathrm{C}$. $\mathrm{H}$, and $\mathrm{N}$ values were corrected formoisture and ash using the amounts of moisture and ash given by the thermogravimetric analysis. The amount of $\mathrm{O}$ was determined by difference from the corrected data. The $\mathrm{H}: \mathrm{C}, \mathrm{C}: \mathrm{N}$, and $\mathrm{O}: \mathrm{C}$ atomic ratios were also calculated.

Solid-state ${ }^{13} \mathrm{C}$ NMR experiments were carried out using a VARIAN INOVA spectrometer at ${ }^{13} \mathrm{C}$ and ${ }^{1} \mathrm{H}$ frequencies of 100.5 and $400.0 \mathrm{MHz}$, resnectively. The techniques used were variable amplitude cross-polarization (VACP); chemical shift anisotropy (CSA) with total suppression of spinning sidebands (TOSS); and recoupled dipolar dephasing (DD) experiments (details are in the Supporting Information).

Principal component analysis (PCA) was carried out using the full VACP spectra obtained, after mean-centering of the data, and principal component regression $(\mathrm{PCR})$ data were obtained from thermo-gravimetric and elemental data.

\section{Results and Discussien}

On average, the $C$ recovery in the HA fraction from the total soil organic C was $30 \%$, and minimal and maximal recoveries were 16 and $46 \%$, respectively. The control soils presented the smaller values (Table SI-1). Based on the thermal analyses data, the HAs had low ash contents, in the range of $0,1-$ $9.2 \%$, averaging $4.5 \%$ (Table SI-1). Representative thermodecomposition curves of HAs extracted from AS-E, AS-C, control soils are shown in Figure S1-2. The thermogravimetric index (TGI) of HAs extracted from anthropogenic soils (AS-F and AS-C) was larger than those for the control soils (Table SI-1).

According to the review by Benites et al. (6) and that of Francioso et al. (30), the first exothermic peak (378-623 $\mathrm{K}$ ) arises from the thermal combustion of polysaccharides, the decarboxytation of acidic groups, and the dehydration of atiphatic hydroxyl strucnues. The second exothermic peak (623-923 K) is related to the combustion of aromatic structures and cleavages of $\mathrm{C}-\mathrm{C}$ bonds.

That indicates that the HAs from anthropogenic samples were more aromatic than those in the controls, and suggests the occurence of polycyclic aromatic nuclei, which have greater thermal resistance.

The HAs from the AS-C were more enriched in $\mathrm{C}$ and depleted in $\mathrm{H}$ (Table SI-1), indicating that the cultivation of these soils had led to the selective degradation of aliphatie structures and a possible relative enrichment in hydrogendeficient, condensed aromatic structures from the older HA precursors, the pyrogenic carbon. The HAs extracted from the anthropogetic soils presented lower $\mathrm{N}$ contents and higher atomic $\mathrm{C} / \mathrm{N}$ ratios (rable S1-1); however, these ratios are in the range for biologically stabilized materials $[26$. Additionally, these HAs bad a lower atomic $\mathrm{H} / \mathrm{C}$ ratio indicating high aromaticity and/or aromatic ring condensation (Figure SI-3). The O/C atomic rait values were variable, 


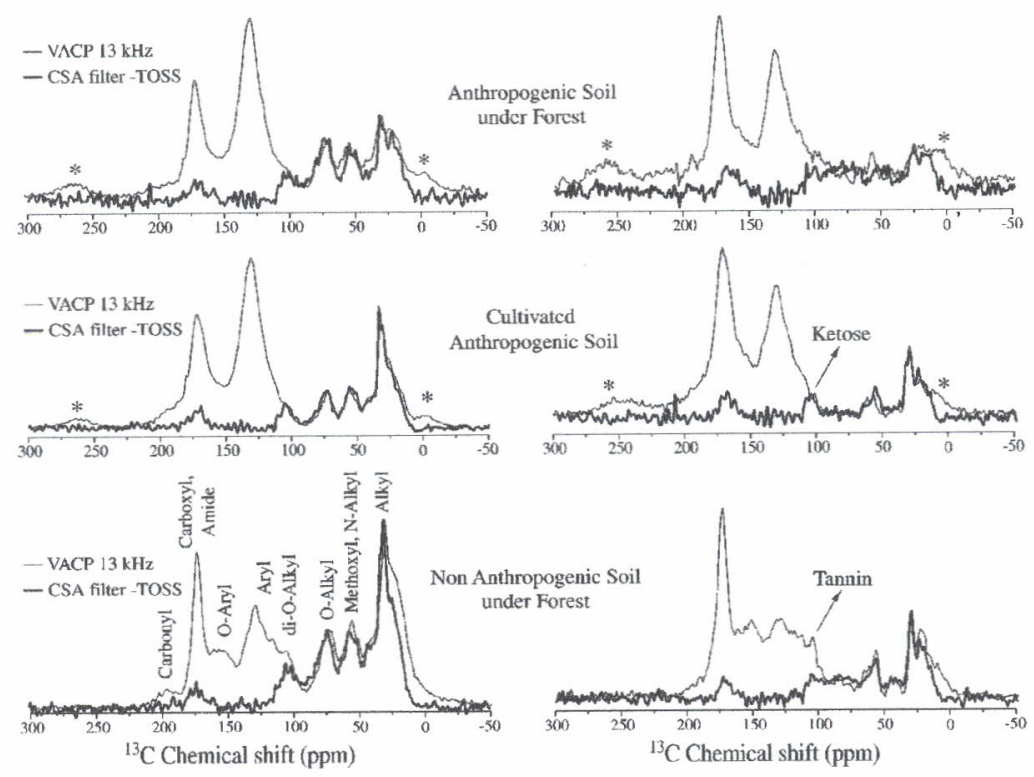

FIGURE 1. Left: Full VACP (13 kHz MAS) spectra of a humic acid sample extracted from Amazonian soils (thin line) and the corresponding VACP-TOSS spectrum (5 kHz MAS) after $35 \mu$ s CSA filter (thick line). Right: Corresponding VACP (13 kHz MAS) spectra after dipolar dephasing with $67 \mu$ s of gated decoupling (thin line) and corresponding VACP-TOSS spectrum (5 kHz MAS) after $35 \mu$ S CSA filter and $40 \mu$ s of gated decoupling (thick line). The symbols $*$ indicate the spinning sidebands.

and there was not a clear tendency for these for the different sample groups.

Although DP is probably the most quantitative ${ }^{13} \mathrm{C}$ NMR technique $(28,31), \mathrm{CP}$ is used routinely because it requires less instrument time $(16,31)$. Among the different crosspolarization $(\mathrm{CP})$ semiquantitative methods (single-amplitude with MAS-CP/MAS; CP with total suppression of spimning sidebands-CP/TOSS, and VACP with high MASVACP/MAS) VACP with high-speed MAS (VACP/MAS) is preferred (31). That is so because the radio frequency ramp used during the Hartmann-Hahn contact provides a more uniform magnetization transfer between ${ }^{1} \mathrm{H}$ and ${ }^{13} \mathrm{C}$ nuclei, making the excitation profile similar in ${ }^{1} \mathrm{H}$ rich or poor and mobile or rigid segments. This opens the possibility of replacing the time-consuming DP/MAS experiments by VACP/MAS for comparison purposes $(16,31,32)$.

The method proposed by Mao and Schmidt-Rohr (28) for quantifying aromaticity by NMR combines the use of high speed MAS DP experiments and low speed MAS CSA filter experiments incorporating TOSS acquisition. However, based on our previous results, that showed that the spectra acquired using an optimized VACP excitation and DP are essentially identical for a sample rich in pyrogenic carbon (32), and reports in the literature $(16,31)$, we opted to replace the DP experiment by the VACP in order to decrease the experimental time. We are aware that the data obtained are not truly quantitative, but these are adequate for the comparisons made in this study.

When trying the calibration of the pulses in a sample rich in pyrogenic carbon, it was not possible to provide a simultaneous inversion of the nuclear spins of the carbons in different chemical groups (32). The presence of graphiticlike structures can induce local magnetic susceptibility heterogeneities (33) and lead to a "reflection" of the excitation pulse: the "skin effect" $(33,34)$. The problem is enhanced when carrying out the CSA filter and TOSS experiments required for the quantification method of Mao and SchmidtRohr (28) because these experiments involve the application of many cascaded $\pi$ pulses that enhance the effect of the pulse imperfections. To overcome this problem we replaced all the $\pi$ pulses of the CSA filter-TOSS by the composite $\pi$ pulses, as suggested by Raleigh et al. (35) and Hagemeyer et al. (36) and recommended by Cook (31). Details of this procedure are in Novotny et al. (32).

The VACP spectra in Figure 1 show patterns that are representative of HAs from the different soil groups. These depict typical signals from alkyl C groups $(0-46 \mathrm{ppm})$, probably of plant origin, such as cutin, suberin, wax, and dehydroxylated lignin side chains with high resistance to degradation (37), or from microbial neo-synthesis (38). The persistence of signals at 21 and $30 \mathrm{ppm}$ in the DD spectra (Figure 1) indicate the presence of terminal $\mathrm{CH}_{3}$ and longchain mobile $\mathrm{CH}_{2}$, respectively $(39,40)$. The signal for methoxyl $\mathrm{C}$ is expected at $56 \mathrm{ppm}$. It overlaps with resonances from $\mathrm{N}$-alkyl C groups with chemical shift in the range 46$60 \mathrm{ppm}$; DD experiments confirmed contributions from methoxyl C. This signal shows lower intensity for anthropogenic soils than for the control soils (Table SI-2), indicating a greater incorporation of lignin and lignin-like residues to the HAs (4I) extracted from control soils. These compounds contribute to the clear signals and shoulders in the chemical shift region of aryl C between 109 and $143 \mathrm{ppm}$ and to the $\mathrm{O}$-aryl signal, while the HAs of the anthropogenic soils present the typical aryl featureless signals of pyrogenic carbon derived HA (16). Additionally, the aliphatic region (carbohydrates, methoxyl, $\mathrm{N}$-alkyl, and alkyl) is more prominent in control soils than in anthropogenic soils.

Although the signals are not well resolved, the spectra indicate that the chemical shift region of O-aryl C (142-164 $\mathrm{ppm}$ ) contains contributions not only from phenyl C, but also from syringyl and guaiacyl units, and from other lignin O-aryl signals. That was especially evident for the control samples that contain greater lignin character. The dominating signals in the chemical shift region of O-alkyl C $(60-90 \mathrm{ppm})$ and di-O-alkyl C (90-109 ppm) derive predominantly from carbohydrates, although the contribution to the signal in this region of ethers and of alcohols from the propenyl side chains of lignins and tannins cannot be ignored (37). A hydrolysis effect from the $\mathrm{HF} / \mathrm{HCl}$ treatment may be responsible for the relatively low contents (Table SI-2) of functionalities at these resonances. The clear signal in the carboxyl $C$ region (156-186 ppm) indicates the high degree 
of oxidation of the samples.

The signal at $105 \mathrm{ppm}$, observed in the DD spectra, cannot be attributed exclusively to aryl-C in condensed tannin, as is cited in the literature (40), but also to ketose anomeric carbon. However, the latter is preserved after application of the CSA filter (Figure 1, right: AS-C) while the former is suppressed (Figure 1, right: control soil). This example shows the importance of different spectral editing techniques to allow the correct assignments of NMR signals.

The HA samples from anthropogenic soils presented higher contents of aryl C, both total and substituted-C, of O-aryl C, and of carboxyl C (Table SI-2). Additionally, the contribution to the control soils HA samples of the methoxyl $\mathrm{C}$ from lignin was greater, indicating that the aromatic region (aryl and O-aryl C) of control soils samples had larger contributions from lignin residues. Therefore, a larger proportion of $\mathrm{O}$-aryl $\mathrm{C}$ of the control soils samples is not from phenolic groups, and consequently, is not contributing to the total acidity. The same conclusion can be drawn in relation to the carboxyl signal; that is, the control soils HAs have greater contributions from amide groups of protein, as indicated by the smaller $\mathrm{C} / \mathrm{N}$ atomic ratio (Table SI-1) and the greater N-alkyl composition (Table SI-2). In this way, the ionisable oxygenated functional groups signals, which could contribute to CEC (carboxyl and O-aryl minus $\mathrm{N}$-alkyl and methoxyl C), were larger for the anthropogenic samples (Table SI-2).

The high carboxyl $\mathrm{C}$ content in pyrogenic carbon derived HAs is well-known. However, artifact formation from the isolation and fractionation methods cannot be ignored, because the alkali-soluble fraction of these highly aromatic HAs requires the presence of hydrophilic groups (21).

The contribution of carbohydrates $(\mathrm{O}$-alkyl and di-O-alkyl C) was larger for the control soils (Table SI-2). These carbohydrates, that resisted the $\mathrm{HF} / \mathrm{HCl}$ treatment, were mainly in ketal form (Table SI-2), since the anomeric $C$ signal remains in double filtered spectra (CSA + DD), indicating that it is an umprotonated $\mathrm{C}(28)$. The $\mathrm{C}$ substituted aryl groups in anthropogenic samples could be underestimated due to polycyclic aromatic structures undetected by CP-NMR (16) or to local anisotropic magnetic susceptibility that broadens the aryl signal. This broadening cannot be removed by MAS, making this signal undetectable, even by DP (33). However, the high correlation between aryl C and TGI $(R=0.86)$, and the arvl $\mathrm{C}$ and atomic $\mathrm{H} / \mathrm{C}$ ratio $(R=-0.90)$ indicate that the NMR data are, at least, semiquantitative. In addition, TGl presented negative correlations with labile groups, such as: alkyl (-0.73); $\mathrm{N}$-alkyl/methoxyl ( -0.83$)$; and carbohydrates $(-0.89)$. That indicates that this index is a good tool to estimate the degree of humification.

The first principal component ( $\mathrm{PCI}$ ) (Figure 2), calculated by PCA, accounted for $61 \%$ of the total variance and is characterized by positive loadings for the pyrogenic carbon aryl signal (broad featureless signal at $130 \mathrm{ppm}$ ) and negative loadings for the signals of carbohydrates, methoxyl, $\mathrm{N}$-alkyl, alkyl $(0-100 \mathrm{ppm})$, and 0 -aryl (151 ppm). The loadings of the PCA are the correlations between the original variables (spectra) and the principal components generated. In the present case, the increase of pyrogenic carbon derived compounds corresponds to a decrease of the contribution of the other compounds (carbohydrates, peptides, lignin etc). Should the contents of some components vary in a set of samples, that variation could be detected by PCA. Thus the PCA approach could be used to separate the components in a mixture. In this way, the positive loadings at $169 \mathrm{ppm}$ can be attributed to carboxyl groups attached to pyrogenic carbon aromatic rings, and the negative loadings at $174 \mathrm{ppm}$ to amide from proteins/peptides (34).

Thus, the larger the scores for this $\mathrm{PC}$, the larger will be the contribution of pyrogenic carbon structures to the
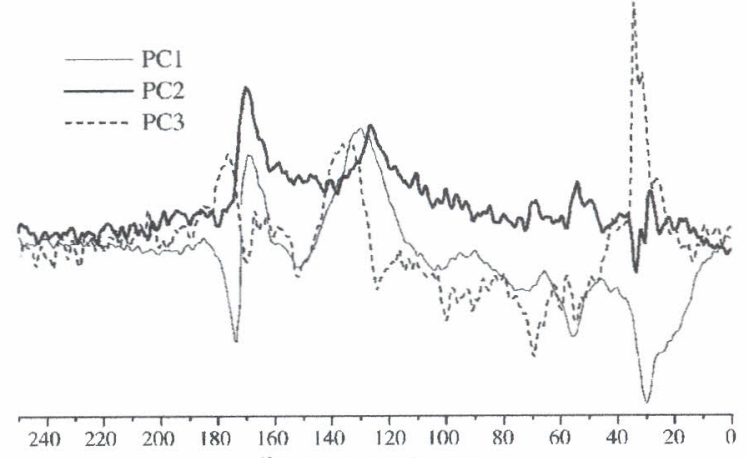

${ }^{13} \mathrm{C}$ Chemical shift (ppm)

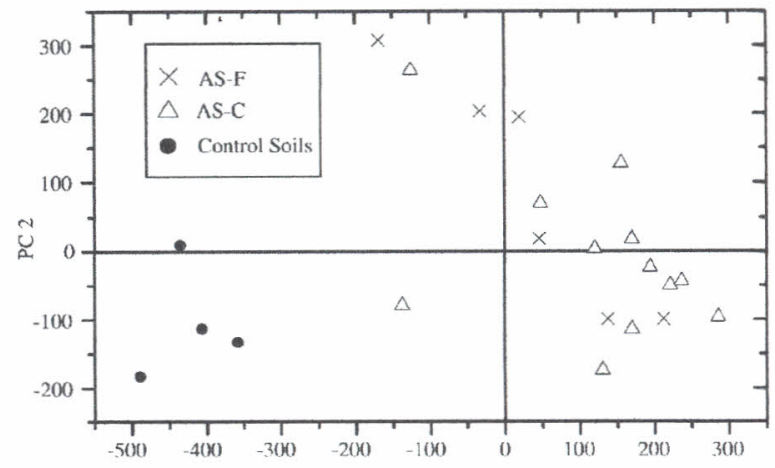

$\mathrm{PC} 1$

FIGURE 2. Upper: Loadings of PCA from full VACP spectra. Lower: Scores of PCA from full VACP spectra. PC1, 2, and 3: Principal components 1, 2, and 3; AS-F: anthropogenic soil under forest; AS-C: cultivated anthropogenic soil; control soils: non-anthropogenic soil.

compositions of the HAs, and these structures are characterized by recalcitrant (aryl) and reactive groups (carboxyl). On the other hand, smaller scores indicate larger contributions of labile structures, and/or structures of lower degrees of humification, such as carbohydrates, proteins, and lignin. This PC separated the control soils samples with smaller scores (Figure 2), and it had positive correlations with TGI $(0.82), 0 / \mathrm{H}(0.82)$, and $\mathrm{C} / \mathrm{N}(0.88)$ atomic ratios, and a negative correlation with the $\mathrm{H} / \mathrm{C}(-0.90)$ atomic ratio. This confirms, by independent methods, that HAs from anthropogenic soils can be characterized with regard to high stability in terms of both structural (NMR and elemental composition) and thermal properties.

The second principal component (PC2) accounted for $21 \%$ of total variance and is characterized mainly by a broad signal at $126 \mathrm{ppm}$ and another at $170 \mathrm{ppm}$. The upfield shift of the aryl peak to $126 \mathrm{ppm}$ is typical of charred residues attributable to polycyclic aromatic structures $(33,37,42)$. The scores of this PC were smaller for the control soils, and varied within the anthropogenic soils group (Figure 2). The same tendency is observed for the first PC, indicating that the cultivation of AS does not alter significantly the quality of HAs and confirms the recalcitrance and resilience of HAs derived from pyrogenic carbon.

The third principal component (PC3) (Figure 2) accounted for $5 \%$ of total variance and is characterized mainly by sharp alkyl (33 ppm), aryl (136 ppm) and carboxyl/amide (177 ppm) signals. Due to negative loadings in the region of $\mathrm{N}$-alkyl groups, this signal can be attributed to carboxyl. Thus these features indicate peripheral incorporation of fatty acids to the aromatic backbone (7). This PC discriminated just one sample (data not shown). 
Despite the fact that there were not significant differences between the NMR spectra obtained by direct polarization and cross polarization (data not shown), and although there were not identifiable shifts of the aryl peaks at $126 \mathrm{ppm}$ in the VACP spectra that would indicate the presence of polycyclic aromatic structures $(33,37,42)$, there is convincing NMR evidence to comoborate the occurrence of polycondensed aromatic structures with carboxylic functionality in the ADE soil HAs. This evidence is provided by the identification, after PCA, of polycyclic aromatic structures with the typical aryl peak at $126 \mathrm{ppm}$. Further evidence is provided by the improved quality of the CSA spectra from applications of composite pulses. This indicates magnetic susceptibility heterogeneities, probably due to graphitic like structures (33).

From the loadings obtained by PCA, it was possible to separate different constituents of HAs, such as pyrogenic carbon-derived compounds (carboxylated aryl structures) and plant derived compounds (carbohydrates, proteins, and lignin). PCA of NMR data has permitted differentiation of functionalities from proteins and lignin from those of pyrogenic carbon. Our data indicate that HAs fiom anthropogenic soils have high contents of aryl and recalcitrant, ionisable, oxygenated functional groups (carboxyl and phenolic C), while the major functionalities in the HAs from adjacent non-anthropogenic soils are oxygenated functional groups, mainly from labile structures (carbohydrates, peptides, and lignin). That would suggest that the HAs from anthropogenic soils are more recalcitrant, and present more stable reactive groups. These differences can, at least in part, explain the higher and more sustainable fertility status of the anthropogenic soils, due the contribution of the OM to the soil CEC.

The data presented give evidence for the occurrence of pyrogenic carbon in the HA fraction of the SOM. The higher OM contents and the physical-chemical properties of the pyrogenic carbon probably have an important contribution to the higher CEC of these soils, and the ashes input contributed to the higher nutrients status. However, just the addition of nutrients would not guarantee the higher fertility, because these could be lost by leaching, for example, especially in the tropical regions. In this way, the combination of nutrient inputs (ashes) with better sorptive conditions (altered pyrogenic carbon) renders these soils more fertile than the similar surrounding soils without pyrogenic carbon imputs. That would indicate possibilities for a modem model of sustainable agriculture based in traditional knowledge.

The use of VACP NMR gave similar results to those obtained by direct polarization, and in a much shorter experimental time. The CSA filter technique, as proposed by Mao and Schmidt-Rohr (28), was not efficient for HA samples extracted from soils rich in pyrogenic carbon, probably as the result of their high magnetic susceptibility. However, the use of composite pulses for TOSS and the CSA filter was shown to be adequate for the study of samples rich in pyrogenic carbon.

\section{Acknowledyments}

We are grateful to the Brazilian Science Agencies Fundação de Amparo à Pesquisa do Estado de São Paulo (FAPESP), Conselho Nacional de Desenvolvimento Científico e Tecnológico (CNPq), and Empresa Brasileira de Pesquisa Agropecuária (EMBRAPA), and to the Science Foundation Ireland and Irish Research Council for Science, Engineering and Technology (IRCSET) for postdoctoral support.

\section{Supporting Intormation Available}

Text giving further experimental details and additional information in the form of two tables and three figures, including a map displaying the sample sites, thermogravi- metric characteristics, elemental compositions, and distribution of ${ }^{13} \mathrm{C}(\%)$, determined by ${ }^{13} \mathrm{C}$ NMR, of humic acids extracted from Amazonian soils. This material is available free of charge via the Internet at http://pubs.acs.org.

\section{Literature Cited}

(1) Kämpf, N.; Woods, W. I.; Sombroek, W.; Kem, D. C.; Cunha, T. J. F. Classification of Amazonian dark earths and other ancient anthropic soils. In Amazonian Dark Earths. Origin Properties, Management; Lehmann, J., Kern, D. C., Glaser, B., Woods, W. I., Eds.; Kluwer Academic Publishers: Dordrecht, 2003; pp 77 104.

(2) Kern, D. C.; D'Aquino, G.; Rodrigues, T. E.; Frazão, F. I. L.; Sombroek, W: Myers, T. P. Neves, E G Distribution of Amazonian dark earths in the Brazilian Amazon. In Amazonian Dark Earths. Origin, Properties, Management; Lehmann, I., Kern, D. C., Glaser, ‘B., Woods, W. I., Eds.; Kluwer Academic Publichers: Dordrecht, 2003; pp 51-76.

(3) Woods, W. I.; McCann, J. M. The anthropogenic origin and persistence of Amazonian dark earths. Yearb. - Conf. Lat. Am. Geogr. 1999, 25, $7-14$.

(4) Costa, M. L.; Kern, D. C. Geochemical signatures of tropical soils with archaeological black earth in the Amazon, Brazil. J. Geochem. Explor. 1999, 66, 369-385.

(5) Roscoe, R.; Buurman, P.; Velthorst, E. J.; Vasconcellos, C. A. Soil organic matter dynamics in density and particle size fractions as revealed by the ${ }^{13} \mathrm{C} /{ }^{12} \mathrm{C}$ isotopic ratio in a Cerrado's oxisol Geoderma 2001, 104, 185-202.

(6) Benites, V. M.; Mendonça, E. S.; Schaefer, C. E. G. R.; Novotny, E. H.; Reis, E. L.; Ker, J. C. Properties of black soil humic acids from high altitude rocky complexes in Brazil. Geoderma 2005 , $127,104-113$

(7) González-Pérez, J.A.; González-Vila, F. J.; Almendros, G.; Knicker $H$. The effect of fire on soil organic matter-a review. En viron. Int. 2004, 30, 855-870.

(8) Druffel, E. R. M. Comments on the importance of black carbon in the global carbon cycle. Mar. Chem. 2004, 92, 197-200.

(9) Glaser, B.; Amelung, W. Pyrogenic carbon in native grassland soils along a climosequence in North America. Global Biogeochem. Cy. 2003, 17, art. no. 1064.

(10) Skjemstad, J. O.; Reicosky, D. C.; Wilts, A. R.; McGowan, J. A Charcoal carbon in U.S. agricultural soils. Soil Sci. Soc. Am. J. $2002,66,1249-1255$.

(11) Skjemstad, J. O.; Taylor, J. A.; Smemik, R. J. Estimation of charcoa (char) in soils. Commun. Soil Sci. Plant Anal. 1999, 30, 2283 2298.

(12) Schmidt, M. W. I.; Skjemstad, J. O.; Gehrt, E.; Kögel-Knabner, I. Charred organic carbon in German chernozemic soils. Eur. 1. Soil Sci. 1999, 50, 351-365.

(13) Ponomarenko, E. V.; Anderson, D. W. Importance of charred organic matter in Black Chernozem soils of Saskatchewan. Can. J. Soil Sci. 2001, 81, 285-297.

(14) Derenne, S.; Largeau, C. A review of some important families of refractory macromolecules: composition, origin, and fate in soils and sediments. Soil Sci. 2001, 166, 833-847.

(15) Masiello, C. A. New directions in black carbon organic geochemisty. Mar. Chem. 2004, 92, 201-213

(16) Simpson, M. J; Hatcher, P. G. Overestimates of black carbon in soils and sediments. Naturuissenschaften 2004, 91, 436440 .

(17) Sombroek, W. G.; Nachtergaele, F. O.; Hebel, A. Amounts, dynamics and sequestering of carbon in tropical and subtropical soils. Ambio 1993, 22, 417-426.

(18) Glaser, B.; Haumaier, L; Guggenberger, G.; Zech, W. The "Terra Preta' phenomenon: a model for sustainable agriculture in the humid tropics. Naturwissenschaften 2001, 88, 37-41.

(19) Skjemstad, J. O.; Clarke, P.; Taylor, J. A. Oades, I. M. McClure, 5. G. The chemistry and nature of protected carbon in soil. Aust. J. Soil Res. 1996, 34, 251-271.

(20) Wolbach, W. S.; Anders, E. Elemental carbon in sediments: determination and isotopic analysis in the presence of kerogen. Geochim. Cosmochim. Acta 1989, 53, 1637-1647.

(21) Kramer, R. W.; Kujawinski, E. B.; Hatcher, P. G. Identification of black carbon derived structures in a volcanic ash soll humic acid by fourier transform ion cyclotron resonance mass spectrometry. Environ. Sci. Technol. 2004, 38, 3387-3395.

(22) Bird, M. I.; Moyo, C.; Veenendaal, E. M.; Lloyd, J.; Frost, P. Stability of elemental carbon in a savanna soil. Global Biogeochem. Cycle $1999,13,923-932$.

VOL. $x x$, NO. $x x, x x x x$ / ENVIRON. SCI. \& TECHNOL. $=E$ 
(23) Schmidt, M. W. I.; Noack, A. G. Black carbon in sojls and sediments: analysis, distribution, implications, and current challenges. Global Biogeochem. Cy. 2000, 14, 777-793.

(24) Swift, R. S. Sequestration of carbon by soil. Soil Sci. 2001, 166, $858-871$.

(25) Glaser, B.; Lehmann, J.; Zech, W. Ameliorating physical and chemical properties of highly weathered soils in the tropics with charcoal - a review. Biol. Fertil. Soils 2002, 35, 219-230.

(26) Clapp, C. E.; Hayes, M. H. B.; Simpson, A. J.; Kingery, W. L. The chemistry of soil organic matter. In Chemical Processes in Soils; Tabatabai, M. A., Sparks, D. L., Eds.; American Society of Agronomy: Madison, WI, 2005; pp 1-150.

(27) Madari, B. E.; Sombroek, W. G.; Woods, W. I. Research on Anthropogenic Dark Earth soils. Could it be a solution for sustainable agriculiural development in the Amazon? In Amazonian Dark Earths: Explorations in Space and Time; Glaser, B., Woods, W. I., Eds.; Springer-Verlag: Heidelberg, 2004; pp 169-182

(28) Mao, J. D.; Schmidt-Rohr, K. Accurate quantification of aromaticity and nonprotonated aromatic carbon fraction in natural organic matter by $\mathrm{C}-13$ solid-state nuclear magnetic resonance. Environ. Sci. Technol. 2004, 38, 2680-2684.

(29) Swift, R. S. Organic matter characterization. In Methods of soil analysis-Part 3. Chemical Methods; Sparks, D. L., Page, A. L.., Helmke, P. A., Loeppert, R. H., Soltanpour, P. N., Tabatabai, M. A. Johnston, C. T., Sumner, M. E., Eds.; American Society of Agronomy and Soil Science Society of America: Madison, WI, 1996; pp 1011-1020.

(30) Francioso, O; Montecchio, D. Gioacchini, P. Ciavatta, C Thermal analysis (TG-DTA) and isotopic characterization $\left({ }^{13} \mathrm{C}\right.$ $\left.{ }^{15} \mathrm{~N}\right)$ of humic acids from different origins. Appl. Geochem. 2005 , $20,537-544$.

(31) Cook, R. I Coupling NMR to NOM. Anal Bioanal. Chem. 2004, $378,1484-1503$

(32) Novotny, E. H.; Hayes, M. H. B.; deAzevedo, E. R.; Bonagamba, T. J. Characterisation of Black Carbon rich samples by ${ }^{13} \mathrm{C}$ solid state nuclear magnetic resonance. Naturwissenshaften 2006 , $93,447-450$.
(33) Freitas, I. C. C.; Bonagamba, T. J.; Emmerich, F. G. ${ }^{13} \mathrm{C}$ high resolution solid-state NMR study of peat carbonization. Energ Fuels, 1999, 13, 53-59.

(34) Fernandes, M. B.; Skjemstad, J. O.; Johnson, B. B.; Wells, J. D.; Brooks, P. Characterization of carbonaceous combustion residues. I. Morphological, elemental and spectroscopic features. Chemosphere 2003, 51, 785-795.

(35) Raleigh, D. P.; Kolbert, A. C.; Griffin, R. G. The effect of experimental imperfections on TOSS spectra. J. Magn. Reson. $1990,89,1-9$.

(36) Hagemever, A.; Van der Putten, D.; Spiess, H. W. The use of composite pulses in the TOSS experiment. J.Magn. Reson. 1991, $92,628-630$

(37) Knicker, H.; González-Vila, F. I; Polvillo, O; González, I. A.; Almendros, G. Fire-induced transformation of $\mathrm{C}$ - and $\mathrm{N}$ - forms in different organic soil fractions from a Dystric Cambisol under a Mediterranean pine forest (Pinus pinaster). Soil Biol. Biochem. 2005, 37, 701-718.

(38) Baldock, J A.; Oades, J. M.; Vassalo, A. M.; Wilson, M. A. Solidstate CP/MAS ${ }^{13} \mathrm{C}$ NMR analysis of bacterial and fungal cultures isolated from a soil incubated with glucose. Aust. J. Soil Res. $1990,28,213-225$.

(39) Hu, W.; Mao, J.; Xing, B.; Schmidt-Rohr, K. Poly(methylene) crystallites in humic substances detected by nuclear magnetic resonance. Environ. Sci. Technol. 2000, 34, 530-534.

(40) Lorenz, K.; Preston, C. M. Characterization of high-tannin fractions from humus by carbon-13 cross-polarization and magic-angle spinning nuclear magnetiç resonance. J. Environ. Qual. 2002, 31, 431-436.

(41) Golchin, A.; Oades, J. M.; Skjemstad, J. O.; Clarke, P. Soil structure and carbon cycling. Aust. I. Soil Res. 1994, 32, 1043-1068.

(42) Smernik, R. J.; Kookana, R. S.; Skjemstad, J. O. NMR Characterization of ${ }^{13} \mathrm{C}$-benzene sorbed to natural and prepared charcoals. Environ. Sci. Technol. 2006, 40, 1764-1769.

Received for review April 19, 2006. Revised manuscript received August 22, 2006. Accepted September 7, 2006.

ES06094IX 